\title{
The Intersection of Realist Traditions and Modern Experiences in Vincent van Gogh's The Road Menders of 1889
}

\author{
Heather Shepherd
}

\begin{abstract}
Last summer I was given the opportunity to work closely with an extensive exhibition of Dutch artist Vincent Van Gogh's paintings at the National Gallery of Canada (through a class run here at the University of Alberta). I focused my research for the class on unpacking the significance of an unorthodox painting in the show entitled The Large Plane Trees (1889), which presents Jean François Millet-inspired digging figures in a markedly diminished and experimental way. Looking to the overt spirituality of Van Gogh's personal writings, Van Gogh's curious obsession of copying Millet's agrarian figures, the influence of Ukiyo-e Japanese woodblock prints, and nineteenth-century politics regarding the depicting of the rural and working classes, this paper gives readers a chance to understand a small portion of the pedagogy, and aims of an artist whose aspirations have been wildly misconstrued by popular and academic media.
\end{abstract}

In the autumn of 1889, Vincent van Gogh observed road menders labouring beneath gigantic trees on the main street of the French town Saint-Rémy where he was staying. He was inspired to paint them immediately. Despite a canvas shortage, Van Gogh captured the scene en plein air, by applying his oil paints onto burgundy dress fabric in the place of a traditional canvas fabric. The scene was later recopied and tweaked in the studio, and the final copy [Figure 2] shares the title The Road Menders with the original version of the work [Figure 1]. These sister paintings are also sometimes titled The Large Plane Trees, The Tall Plane Trees or even Rue a Saint-Rémy. Cornelia Homburg wrote of The Road Menders that the portrayal of diggers can be read as an attempt to illustrate the cycle of life, and further reflected that the subject matter of labour could also be symbolic for Van Gogh's own difficulties during his stay at Saint-Rémy. ${ }^{1}$ Because I am unable to find any other scholarship involving the specific analysis of Van Gogh's The Road Menders, the goal of my research is to explore what the significance of The Road Menders is in relation to Van Gogh's other images of diggers created in the final two years of his life. As source material, I look mainly to Louis van Tilborgh's publication entitled Van Gogh and Millet, because of the intimate connection Van Gogh cultivated between his own digging figures, and those of the French Barbizon painter Jean-François Millet. In fact, Van Tilborgh stresses in his work V an Gogh and Millet that one of Van Gogh's greatest desires concerning art was to successfully translate or update the teachings of Millet into Van Gogh's own contemporary generation. ${ }^{2}$ In my essay I will present an analysis of The Road Menders in relation to Millet's images of digging figures, as well as in relation to Van Gogh's other images of digging figures. I aim to develop a dialogue concerning the intersection of both religious and socio-political commentary in the art of select $19^{\text {th }}$-century avant-garde artists, in relation to the overarching motif of the digging figure. I will also discuss Van Gogh's absorption of Japanese Ukiyo-e techniques, and why these techniques were an important influence for The Road Menders. Through these smaller explorations regarding the manner in which artists use the motif of the digging figure or labourer in

\footnotetext{
${ }^{1}$ Cornelia Homburg, The Copy Turns Original: Vincent van Gogh and a new approach to traditional art practice (Amsterdam and Philidelphia: John Benjamins Publishing Co., 1996), 90.

${ }^{2}$ Van Tilborgh, Van Gogh and Millet (Zwolle: Waanders b. v. Printers and Publishers, 1989) 64.
} 
order to adapt, utilize, or create commentary, I will argue that the original The Road Menders painting, as featured in the National Gallery's Van Gogh Up Close exhibition, can be seen as a successful fulfillment of the role of updating the work of Millet.

Before I get to analysing the evolution of Van Gogh's digging figures, I think it is of the foremost importance to outline Van Gogh's relationship to Millet and the peasant subject. To put it simply, Van Gogh loved Millet's apparent devotion to Christianity, and to painting. In Van Gogh's extremely high opinion, Millet had actually captured the doctrine of Christ in his paintings. ${ }^{3}$ In a more complex way, through collecting his prints, mimicking his artwork, and quoting his ideas in letters, Van Gogh psychologically and by means of physical evidence-as in art-positioned himself as a sort of apprentice under the posthumous Millet. Hundreds of Van Gogh's works, both in charcoal and in oil, are direct visual quotes of this master of the agrarian figure. In fact, despite all the copying and borrowing from other artists such as Eugene Delacroix, Paul Renouard, Claude Monet, and Charles Angrand, Jennifer A. Thompson's essay Van Gogh and Close-Up Techniques in 19 ${ }^{\text {th }}$ Century French Painting states that there is no other artist Van Gogh made more copies after than that of his his so-called 'Father Millet.'

In 1882 Van Gogh read Alfred Sensier's 1881 publication Jean-Francois Millet, Peasant and Painter, which was an in-depth look at Millet, and coincidentally the first publication of this size which leant its focus to documenting the life of a 'peasant painter.' Van Gogh read Sensier's biography of Millet in an avid, almost fanatic delight. Apparently, Van Gogh's passion for this biography was only surpassed by his passion for studying his Bible. ${ }^{5}$ Much of the admiration Van Gogh felt for Millet was born out of the important commonalities Van Gogh perceived between himself and Millet. Sadly, often the reality of Millet did not match up. Sensier's biographic work largely idealized Millet's choices to live and paint in a rural setting, and so, problematically, Van Gogh's image of Millet was quite skewed in comparison to how we view Millet today. For example, today we know that although Millet outfitted himself in peasant garb and lived in the countryside, he preferred the conversation and company of intellectuals, city people, and artists. Van Tilborgh also notes Millet did not live in poverty for the entirety of his career but created a lucrative business of painting peasants after the 1850s. ${ }^{6}$ These two details certainly do not fit the iconic image Van Gogh formed of Millet. The inaccurate projection that Van Gogh formed was also due in part to Van Gogh's negligence of Millet's less religious paintings (such as Killing the Hog, 1867), and to Van Gogh's personal disposition towards seeing religious themes, and beauty, in art and country-life. Van Tilborgh states that "Van Gogh [regarded] Millet as the prophet of an indeterminate sort of religion," and that "[i]n search of his own inner voice in the arduous process of growing up, [Van Gogh] suddenly discovered Millet as a new psychologically acceptable mentor for both his spiritual and artistic development," painter who loved the destitute, and in return was granted a somewhat romantic communion with the supernatural.

As Van Gogh was largely a self-taught, his process of gridding-out and then recreating the paintings and sketches of other artists is not considered unorthodox for his early years. Van Gogh cherished

\footnotetext{
3 Vincent Van Gogh, Vincent van Gogh - The Letters, ed. Leo Jansen, Hans Luijten, and Nienke Bakker (Amsterdam and The Hague: Van Gogh Museum \& Huygens ING, Version December 2010), url: http://www.vangoghletters.org, 632.

${ }^{4}$ Jennifer A. Thompson, "Van Gogh and Close-Up Techniques in19th-Century French Painting", Van Gogh Up Close (New Haven and London: Yale University Press, 2012) 71.

${ }^{5}$ Van Tilborgh, Van Gogh and Millet, 17.

${ }^{6}$ Van Tilborgh, V an Gogh and Millet, 15.

7 Van Tilborgh, V an Gogh and Millet, 16-17.
} 
Millet`s rendering of the human figure, and loved Delacroix`s strength as a colorist, and so taught himself after their work. Though he saw quite a lot of the paintings in person, or at least in color, in his life, the images he worked after were exclusively black-and-white (because of his meager budget), and so Van Gogh in a sense made-up the colors in his oil reproductions. He also made effort to recreate the images in his own style of thick, directional brushwork, and because of these creative alterations, Van Gogh referred to these sets of images as "translations" instead of copies. ${ }^{8}$

Academically, much attention has been paid to the symbolism of Van Gogh's agrarian diggers and labourers done from the Millet originals. In the religious sense, Van Gogh's diggers serve as embodiments of spiritual messages of Christian theology - this is one of purposes they serve in the oeuvre of Millet as well. Because of their self-imposed hunching posture, and their inevitable intersection with dirt and physical exertion, digging figures have become natural signifiers for struggle, exhaustion, and discipline. Further, the physical involvement required for digging leaves little energy for scholarly pursuits or high-minded thinking, and so I think demanding respect for digging figures also demands respect for actions over words or ideas. This celebration of action relates to the Christian doctrine of spreading and demonstrating faith by actions, not thoughts.

Looking to specific works, Millet's Man Turning Over the Soil [Figure 3] of 1847-1850 expresses similar themes to his monumental painting The Sower of 1850. The Sower marked a breakthrough in Millet's techniques of communicating of the virtue of hard work, and for illustrating the sense of communion with nature, in a way that demands respect. ${ }^{9}$ Man Turning Over the Soil offers a more secluded, humble tone than The Sower however, probably because of the aforementioned connotations of the self-disciplining nature of digging figures. Van Gogh made multiple variations of both The Sower and Man Turning Over the Soil. Van Gogh`s variation of Man Turning Over the Soil, that I have chosen to include at the back of this essay, [Figure 4] like many of his translations of Millet`s work, appears more hopeful than the originals. Van Gogh`s translation Two Men Digging is made more hopeful by the use of experimental, more saturated colours, and because of the inclusion of an extra figure (sometimes seen in Millet`s plans for the painting). The use of a pair of diggers, as opposed to a single one, creates a sense of companionship and bonding within the confines of a difficult task-this is yet another link to Christian doctrines of how fellowship and community are important aspects to maintain faith in the face of life`s tests. Basically all of the works about diggers by both Van Gogh and Millet-until The Road Menders - use the motif of the digger as a departure point to address the repetitive, tiresome, and back-breaking labours all individuals must face in order to gain reward in the afterlife, by addressing the reward that the diggers gain by digging (which is temporary survival on Earth). Van Tilborgh states that Van Gogh really did not elaborate on the motif of the digger very much, ${ }^{10}$ however, he does not consider The Road Menders in his scholarship.

The depiction of digging labourers also requires consideration in relation to the Realist discourse and social commentary of the $19^{\text {th }}$ century often intertwined with diggers. Millet is once more central to the history of the motif of the digging figure in this respect. Realist painters such as Gustave Brion and Millet often created images depicting the potato harvest to transmit socio-political messages. Once again Van Tilborgh provides an explanation for Realist painters interests in potatoes: "Generally scorned as fit only for animals, the potato became increasingly important as a staple food of the rural poor in the $19^{\text {th }}$ century, and it remained almost emblematic of poverty." 11 Images of

\footnotetext{
${ }^{8}$ Van Gogh, Vincent van Gogh - The Letters, ed. Jansen, Luijten, and Bakker, 851.

9 Petra ten-Doesschate Chu, "The Revolution of 1848 and the Emergence of a Realism in France," Nineteenth Century European Art 2 $2^{\text {nd }}$ ed (Upper Saddle River, New Jersey: Pearson Pretence Hall, 2006), 263.

10 Van Tilborgh, Van Gogh and Millet, 94.

11 Van TIlborgh, Van Gogh and Millet, 34-35.
} 
potato harvesting usually include or focus on digging peasants (in my experience), and so the motif of the digging figure is very strongly tied to the most impoverished, desperate, and dire subjects. Gustave Brion's Potato Harvest during the Rhine Flood of 1852 [Figure 5] is a great example of the kind of social dialogue Realist painters were developing using the digging motif. In Brion's image, the peasants are modeled in mid-action, and their limbs are shown stretching out in diagonalstransmitting a sense of dynamism, movement, and speed. The peasants are in filthy, ragged clothes, and are desperately trying to save their crop of potatoes from flood waters by digging them out through the mud. There are no heroes in this painting; the peasants look exhausted and their bowed heads instill a sense of fear for their situation, not respect. The painting is clearly meant to inspire opposition to the status quo which placed people like these peasants in such sombre situations. Van Tilborgh states that Van Gogh almost certainly knew of the social commentary the art critic Théophile Silvestre wrote in inspiration of Brion's digging figures ${ }^{12}$.

Gustave Courbet was another French painter interested in creating images which combat traditional styles and subjects of academic painting. Courbet was of the political radical left, and often purposefully and in very public ways rallied for increased liberalization of the Second Empire. Courbet was much more involved in politics than Millet, and although both artists exhibited paintings of a radical nature at the Salon, Millet's other shows simply did not inspire the specific political dialogue that Courbet's shows like his exhibition in Dijon of May 1870 inspired. ${ }^{13}$ Like Brion and Millet, Courbet depicts laborers to spark social criticism. Courbet's The Stone Breakers (1849-1850) [Figure 6] has often been analyzed as an image which addresses the cyclical nature of poverty (as in the idea that if you are born poor, you will die poor) because of the age Courbet has chosen for his labourers. ${ }^{14}$ Van Gogh knew Courbet's images well, and studied them alongside his collection of Millet, Rembrant, Renouard, and Delacroix images. Although there are no digging figures in The Stonebreakers, I see many similarities between The Stonebreakers and The Road Menders in both composition and subject. One similarity is that both sets of labourers are breaking their backs in the service of urban expansion (as in the construction of roadways). Another aspect the two paintings share that in both scenarios dynamism is provided through intersection of the natural world with the laborers. In The Stonebreakers the diagonal jutting of the horizon line reminds the viewer of the harsh, beautiful, untameable quality of the natural world, despite the labourer's attempts to break it. In The Road Menders, the expressive colors used on the trunks of the plane trees in the image give the trees an amazing sense of life, energy, and celebration. Because of Van Gogh's tendency to be informed about other painter's work, and because of his interest in interpreting other painter's work, I think The Road Menders is Van Gogh's way of continuing the conversation about labourers that Courbet and all these aforementioned artists and critics had started. Further, as Van Gogh held all these artists in such high regard, spent so much time thinking about them, and for the most part understood their dispositions in an in-depth manner, I think that Van Gogh's choice to create a scene around road menders in the manner that he did was a way for him to theoretically speak to these old artists and transmit his personal thoughts on their past political agendas and techniques.

Linda Nochlin, in the essay "Van Gogh, Renouard, and the Weaver's Crisis in Lyons," from her publication The Politics of Vision, describes Van Gogh's images of labour as being reformist in

\footnotetext{
12 Van Tilborgh, Van Gogh and Millet, 35.

13 Paul B. Crapo, "Art and Politics in the Côte-D`Òr: Gustave Courbet`s Dijon Exhibition of May 1870," French History 9.33 (1995):317, accessed June 14, 2012, doi: 10.1093/fh/9.3.315.

${ }^{14} \mathrm{Chu}$, "The Revolution of 1848 and the Emergence of a Realism in France," Nineteenth Century European Art 2nd ed, 263.
} 
attitude, but not radical - they are not a call to action. ${ }^{15}$ In this way, Van Gogh is aligning himself more with the political and social ideals of his Father Millet instead of Courbet or other radicals. She further clarifies that if Van Gogh 's images are in some sense a call to action, then they depend on appealing to the consciousness of the prosperous and powerful, and not to notions of classconsciousness and a worker's revolution. ${ }^{16}$ Nochlin does not understand Van Gogh's oeuvre to be one concerned with rallying a revolutionary movement or supporting any specific political party.

Personally, I agree with Nochlin's assessment, and see Van Gogh's images of diggers to be more concerned with exploring the juxtaposition of urban and rural environments than with inspiring revolution. Van Gogh also seems to be concerned with what is being lost with increased industrialization. To me, the mesmerizing quality of the strong trees in The Road Menders makes me certain that Van Gogh found it important to comment on the fact that the exponential urban expansion which was driving the Modern Era was alienating the lower classes (and all classes for that matter) from being in communion with nature. As Van Gogh saw God in nature, the logical conclusion to this observation is that Van Gogh's image is meant to address the disconnect with God, and tradition that was occurring at this time by addressing the labour's disconnect from their traditional surroundings of fields. In this way Van Gogh is altering the lessons of Christianity in relation to peasants taken from Millet, and applying them to his generations Modern issues of urban alienation from nature.

Comparing The Road Menders with Van Gogh's more orthodox images of diggers, reveals that The Road Menders was a clearly a painting Van Gogh pulled in an experimental direction. Van Gogh's earlier diggers, are timeless because of their lack of individuality, and by their never ceasing attention to their task at hand, but in The Road Menders, this paradigm is broken down. The digging labourers can no longer be considered timeless because their environment is not timeless-it is contemporary to the painting's historical date of creation. Thus, the socio-political issues and juxtapositions involved with urban labour and city life at the time of the creation of the painting cannot be ignored or glazed over. Finally, Van Gogh is moving the motif out of the indistinct, unmechanized world Millet painted, and placing it in a contemporary scenario. The result was a very strong and creative product which embodied a brilliant way to bring the religious force of Millet's agrarian images into new generations. This vibrant scene which composits the view of a town with urban walkers, colossal, writhing tree trunks, and urban workers, offers a much more stimulating and complex subject matter than any other Van Gogh image of diggers. Van Gogh has deliberately leant the monumentality of the scene to the tree trunks over the figures this time, allowing nature to be the object that portrays a religious message and demands respect. In this way, Van Gogh is diminishing respect for the diggers. Unlike any of Millet or Van Gogh's other genre scenes depicting labour, in The Road Menders the diggers are small, mostly uninteresting, and have barely any opacity to them. The reduced size of Van Gogh's labourers is not anticipated in earlier works. The large rectangular stones that surround the road menders appear far too heavy to carry for their thin, sinuous bodies. I also find it interesting that all the man-made items involved in the painting are limp, or not working. Notice that the green street-light is off, that the cart is empty and out of use, and that there is no glow of hearth of light coming from inside the window spaces. I think this stagnation of human objects that is occurring speaks once again to a more overpowering and wild role of those elements which cannot be regulated-nature, time, death, and the supernatural.

\footnotetext{
15 Linda Nochlin, “Van Gogh, Renouard, and the Weaver`s Crisis in Lyons ", The Politics of Vision, Essays on $19^{\text {th }}$-Century Art and Society (New York: Harper and Row Publishers, 1989), 110.

16 Nochlin, The Politics of Vision, 110.
} 
Compositionally, The Road Menders harkens to Japanese woodblock prints which Van Gogh collected and sometimes copied. ${ }^{17}$ The print Rough Sea at Shichiri Beach in Sagami Province [Figure 8], of 1852 is a strong work by Ando Hiroshige which most clearly exhibits the Ukiyo-e compositional device of placing muscular, organic objects in the foreground, and including in the scene tiny worker figures as if as an afterthought. Always, the monumentality and descriptive mark-making of the close-up objects presents a message of the feebleness of the human figure in comparison. This diminishing of the human figure seems to speak to the limitations of human control. Van Gogh s way of dividing the picture plane into triangular or diagonal sections, and using a tipped-up, uncalculated perspective is also adapted from Ukiyo-e prints and the tradition of Asian art ${ }^{18}$.

Overall, because Van Gogh subscribed to Millet's beliefs that being close to nature is ideal, and because we know Van Gogh to have mostly disliked cities, it is certainly not a stretch to assert that The Road Menders portrays sentiment against his rapidly industrializing world. In The Road Menders, Van Gogh has clearly created a scene where nature demands the most respect and is most beautiful, and where urban work is ugly, depressing, and inglorious. The dialogue that goes along with thisespecially when considering the majestic earlier diggers of Millet-is that rural labour contains worth because of its proximity to the natural world, and because urban labour is removed from nature, it is of less worth. Urban labour is more degrading and more pitiful; urban labour does not seem to have a sense of communion with God or growth, and therefore it is not hopeful, and there is little to be respected in it or learn from it. This disconnect with God and worth in urban labour is highly important as the second half of the $19^{\text {th }}$ century contained utterly massive migrations of people moving away from their land due to revolutions, wars, famine, and radical changes in work distribution (rural work forces decreased as urban centres expanded and demanded labour.) ${ }^{19}$ So, the focus on the anthropomorphic tree trunks by Van Gogh can be seen as an opposition to the Modern Era's values of progress, technological advancement, science, and capitalism. Instead Van Gogh is advocating for the values of faith, and communion with nature.

It is curious that Van Gogh, after reprocessing this original scene The Road Menders only once, moved back to making sheet after sheet of copies of Millet's diggers. [Figure 9] Because of the return to focusing on translating Millet in a more obvious manner, I must postulate as to whether Van Gogh ever personally felt that he had completed his goal of updating Millet's works. Perhaps the continued preoccupation with sketching Millet's diggers is evidence that Van Gogh himself did not see The Road Menders as I do. To this effect, I see The Road Menders as having further significance in relation to the other works undertaken in the last years of his life, as it reveals some insight into Van Gogh`s personal lack of confidence and unwillingness to consider his talents of being on par with Millet.

To conclude, I argue that despite Van Gogh`s possible lack of confidence in the painting, I think The Road Menders can be read as the strongest painting to make the argument that Van Gogh did succeed in pushing socio-political art forward. Van Gogh contributed by pulling Millet`s motif of the solemn digger into the world of urban labour and wage labour, without losing the monumentality and respect for nature and spirituality embedded in the compositional techniques. The synthesis that occurs in The Road Menders between the Ukiyo-e zoomed-in composition, the motif of the digging figure, and the use of expressive colour and brushwork signature to Van Gogh, certainly expands the

\footnotetext{
${ }^{17}$ Cornelia Homburg, “Tree Trunks,” Van Gogh Up Close (New Haven and London: Yale University Press, 2012$), 236$. 18 Jonathan Neaman Lipman, Barbara Molony, and Michael Robinson, "Chapter Six: Traditionalist Reforms and the Origins of Modernity (1860s-1895)," Modern East Asia: An Integrated History (Hong Kong: Pearson Pretence Hall/Laurence King Publishing, 2012), 185.

${ }^{19} \mathrm{Chu}$, "The Revolution of 1848 and the Emergence of a Realism in France," Nineteenth Century European Art $2^{\text {nd }}$ ed, 267.
} 
digging motif exponentially, making Millet more relevant, useful, and accessible to the people of a more urbanized world.

\section{Bibliography}

Chu, Petra ten-Doesschate. "The Revolution of 1848 and the Emergence of a Realism in

France," Nineteenth Century European Art. $2^{\text {nd }}$ ed. 257-267. Upper Saddle River, New Jersey: Pearson Pretence Hall, 2006.

Crapo, Paul B. "Art and Politics in the Côte-D`Òr: Gustave Courbet`s Dijon Exhibition

of May 1870," French History 9.33 (1995). 315-340. Accessed June 14, 2012.

DOI: $10.1093 / \mathrm{fh} / 9.3 .315$

Homburg, Cornelia. The Copy Turns Original: Vincent van Gogh and a new approach to traditional art practice. Amsterdam and Philadelphia: John Benjamins Publishing

Company, 1996.

Homburg, Cornelia. “Tree Trunks," Van Gogh Up Close. 236-247. New Haven and London:

Yale University Press, 2012.

Juneja, Monica. “The Peasant Image and Agrarian change: Representations of Rural Society in

Nineteenth-Century French Painting from Millet to Van Gogh,'Journal of Peasant Studies15.4 (1988). 445-474. Accessed June 2, 2012. DOI: 10.1080/03066158808438373

Lipman, Jonathan Neaman, Barbara Molony, and Michael Robinson. "Chapter Six: Traditionalist

Reforms and the Origins of Modernity (1860s-1895)," Modern East Asia: An

Integrated History. 172-207. Hong Kong: Pearson Pretence Hall/Laurence King

Publishing, 2012.

Nochlin, Linda. The Politics of Vision: Essays on 19th century art and vision. New York: Harper and Row, 1989.

Thompson, Jennifer A. "Van Gogh and Close-up Techniques in 19th-century French Painting,"

Van Gogh Up Close. 66-97. New Haven and London: Yale University Press, 2012.

Tilborgh, Louis van. Van Gogh and Millet. Zwolle, The Netherlands: Waanders, 1989.

Sund, Judy. "The Sower and the Sheaf: Biblical Metaphor in the Art of Vincent Van Gogh," Art

Bulletin 70 (1988). 660-676. Accessed June 2, 2012. DOI: 10.2307/3051107

Van Gogh, Vincent. Vincent van Gogh - The Letters. Ed. Leo Jansen, Hans Luijten, Nienke

Bakker. Amsterdam \& The Hague: Van Gogh Museum \& Huygens ING, Version December 2010. Url: http://www.vangoghletters.org. 


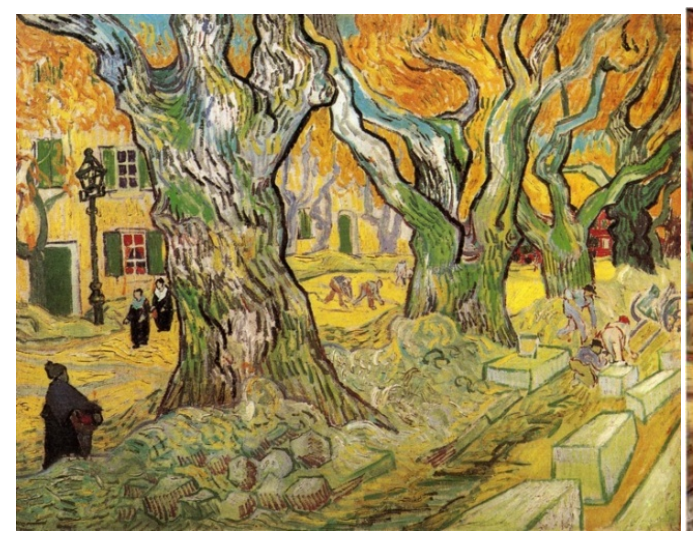

Figure 1: Vincent van Gogh

The Road Menders, 1889

Oil on canvas

http://www.artsunlight.com/artist-NV/N-V0002-Vincen

t-Van-Gogh/N-V0002-0376-large-plane-trees-

the-road-menders.htm

Accessed June $15^{\text {th }}, 2012$

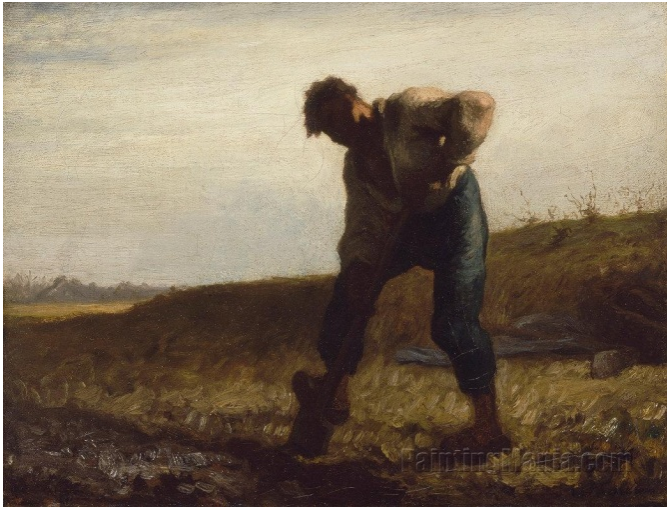

Figure 3

Jean François Millet

Man Turning Over the Soil, 1847-1850

Oil on canvas

http://popartmachine.com/art/BMFA-BMFA.173-

14/JEAN-FRAN\&CCEDIL\%3bOIS-MILLET-MAN TURNING-OVER-THE-SOIL-ABOUT-1847-50

Accessed June $15^{\text {th }}, 2012$

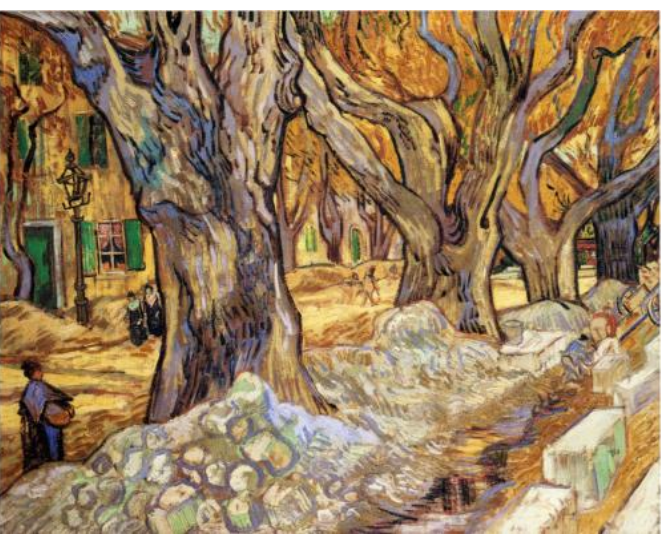

Figure 2: Vincent van Gogh The Road Menders, 1889

Oil on dress fabric

http://www.wikipaintings.org/en/vincent-van - gogh/large-plane-trees-1889

Accessed June $15^{\text {th }}, 2012$

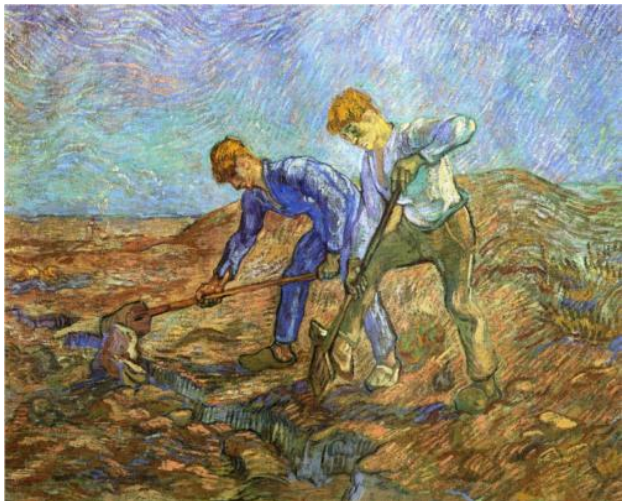

Figure 4

Vincent van Gogh (after Millet)

Two Men Digging, 1889

Oil on canvas

http://www.vangoghgallery.com/catalog/Painting/641/TwoPeasants-Digging-(after-Millet).html

Accessed June $15^{\text {th }}, 2012$ 


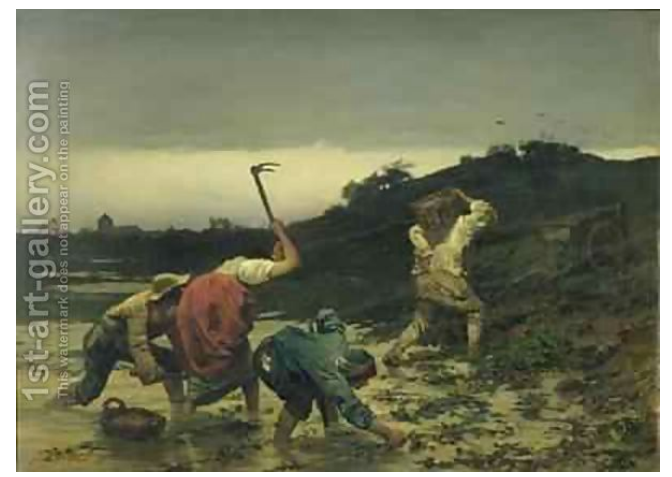

Figure 5: Gustave Brion

Potato Harvest during the Rhine Flood of 1852, 1853

Oil on canvas

http://www.1st-art-gallery.com/thumbnail/324588.jpg

Accessed June $15^{\text {th }}, 2012$.

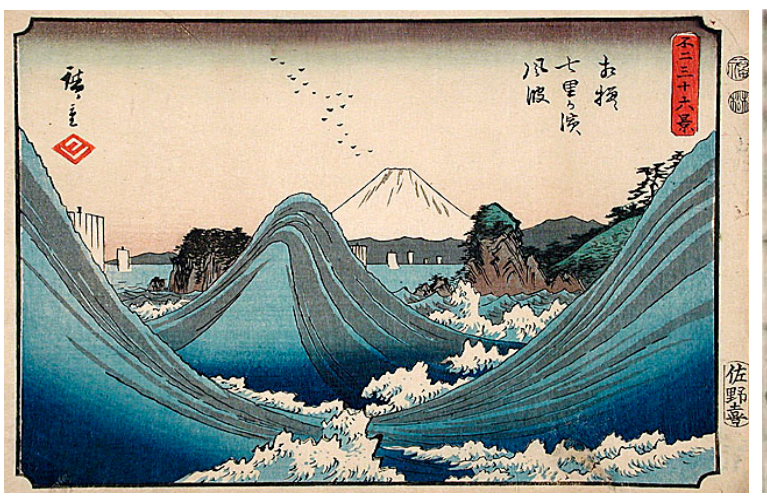

Figure 7: Ando Hiroshige

Rough Sea at Shichiri Beach in Sagami Provence, 1852

Woodblock Print (ink on paper)

http://cybermusee.com/case/cybergallery/pop_galleryView.asp?seq=15201

Accessed June $15^{\text {th }}, 2012$

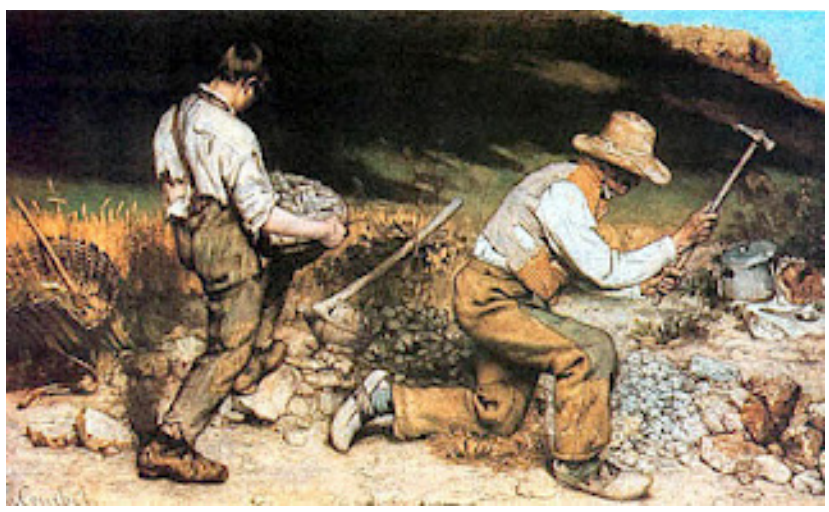

Figure 6: Gustave Courbet

The Stonebreakers, 1849-1850

Oil on canvas

http://emjayarthistory.blogspot.ca/2012/04/gustave-courbet.html Accessed June 15 ${ }^{\text {th }}, 2012$.

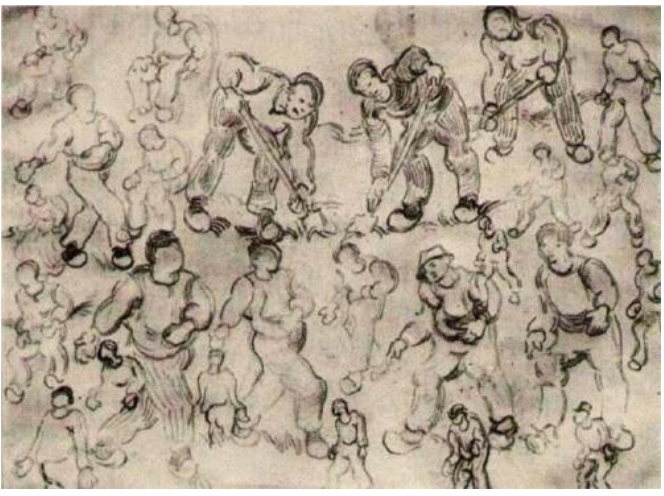

Figure 8: Vincent van Gogh Sheet of Diggers Sketches, 1890 pencil and charcoal on paper http://www.wikipaintings.org/en/vincent-van-gogh Accessed June 15 ${ }^{\text {th }}, 2012$ 